\title{
The Effect of E-Learning Learning Model on Student Motivation
}

\author{
Febi Yuandini, Sarkadi, Nurzengky Ibrahim \\ Universitas Negeri Jakarta \\ yuandinifebi@gmail.com
}

\author{
Article History \\ accepted 1/09/2020
}

approved 4/10/2020

published 1/12/2020

\begin{abstract}
Learning is a process of interaction between teachers and students and the elements in them. The teacher is the most dominant factor that determines the quality of learning. Education is the first step for someone to know something, both himself, the surrounding environment and when interacting with others, with education, a person can become a human who is trained and has skills in life. Especially during this pandemic, which is a widespread effect of the influence of Covid-19, so that distance learning is something that should be done, as a preventive measure from the dangers of the disease. The purpose of this study was to determine whether the ELearning learning model can affect student learning motivation. The population and sample in this study were students at Islamic Village Senior High School 2020/2021 academic year. The method used in this research is descriptive quantitative with One-shot case study. Data analysis by calculating the correlation coefficient and its significant test, which is then followed by determining the regression equation. The results of this study indicate that the E-Learning learning model influences student learning motivation.
\end{abstract}

Keywords: e-learning, learning motivation

\begin{abstract}
Abstrak
Pembelajaran merupakan suatu proses interaksi antara guru dan siswa beserta unsur yang ada di dalamnya. Guru merupakan faktor yang paling dominan yang menentukan kualitas pembelajaran. Pendidikan merupakan langkah awal bagi seseorang mengenal sesuatu, baik dirinya sendiri, lingkungan sekitar maupun saat berinteraksi dengan sesama, dengan adanya pendidikan maka seseorang bisa menjadi manusia yang terlatih dan memiliki kecakapan dalam hidup. Apalagi pada masa pandemi ini, yang merupakan efek meluas dari pengaruh adanya Covid-19, sehingga pembelajaran jarak jauh merupakan hal yang sudah seharusnya dilakukan, sebagai tindakan pencegahan dari bahaya penyakit tersebut. Tujuan penelitian ini adalah untuk mengetahui apakah model pembelajaran E-Learningdapat berpengaruh terhadap motivasi belajar siswa. Populasi dan sampel dalam penelitian ini adalah siswa di SMA Islamic Village tahun ajaran 2020/2021. Metode yang digunakan dalam penelitian ini adalah kuantitatif deskriptif dengan disain One-shot case study. Analisis data dengan menghitung koefisien korelasi dan uji signifikan nya yang kemudian dilanjutkan dengan menentukan persamaan regresinya. Hasil dari penelitian ini yaitu menunjukkan bahwa model pembelajaran E-Learning mempengaruhi motivasi belajar siswa.
\end{abstract}

Kata Kunci : E-learning, motivasi belajar

Social, Humanities, and Education Studies (SHEs): Conference Series https://jurnal.uns.ac.id/shes

p-ISSN 2620-9284

e-ISSN 2620-9292

This work is licensed under a Creative Commons Attribution-ShareAlike 4.0

International License. 


\section{PENDAHULUAN}

Pembelajaran merupakan suatu proses interaksi antara guru dan siswa beserta unsur yang ada di dalamnya. Guru merupakan faktor yang paling dominan yang menentukan kualitas pembelajaran. (Herman, n.d.)Pendidikan merupakan langkah awal bagi seseorang mengenal sesuatu, baik dirinya sendiri, lingkungan sekitar maupun saat berinteraksi dengan sesama, dengan adanya pendidikan maka seseorang bisa menjadi manusia yang terlatih dan memiliki kecakapan dalam hidup. Pendidikan yang diajarkan berusaha untuk mendewasakan seseorang yang belum dewasa, agar dapat mengetahui sesuatu yang baik dan benar, yang harus dilakukan dan yang harus ditinggalkan.

Pendidikan menentukan keberhasilan suatu bangsa, melalui pendidikan dapat membentuk kepribadian yang luhur, akhlak yang mulia lagi berbudi pekerti yang baik. Pendidikan dapat dilakukan dimana saja, salah satunya melalui sekolah, melalui pembelajaran di kelas. Berlangsungnya pembelajaran dikelas sangat mempengaruhi berhasil atau tidaknya suatu proses pendidikan, dilihat dari output yang dikeluarkan, yaitu keberhasilan peserta didik dalam memahami pelajaran, yang diaplikasikan melalui tindakan dan prilaku dalam kehidupan sehari-hari, yang memiliki budi luhur yang tinggi, karena pembelajaran tidak hanya selalu menghasilkan pengetahuan dalam diri seseorang, melainkan juga perubahan dalam tata cara berprilaku.

Pendidikan adalah jalan terang yang menunjukkan kepada manusia arah yang benar untuk Ionjakan. Tujuan pendidikan bukan hanya membuat siswa melek huruf tetapi menambah pemikiran rasional, berpengetahuan dan dapat mandiri.Ketika ada kemauan untuk berubah, ada harapan untuk kemajuan dalam bidang apapun.Kreativitas dapat dikembangkan dan inovasi menguntungkan baik siswa maupun guru.

Pembelajaran merupakan unsur yang sangat mendasar dalam penyelenggaraan pendidikan. Seperti yang diungkapkan oleh Rusman, (dalam rusman,dkk. 2011:15) bahwa "Pembelajaran merupakan proses dasar dari pendidikan, dari sanalah lingkup terkecil secara formal yang menentukan dunia pendidikan berjalan baik atau tidak".

Kita hidup di era teknologi informasi dan banyak orang, terutama siswa di sekolah, tergantung pada komputer untuk melakukan pekerjaan dan sebagian besar sekolah telah menyadari bahwa menggunakan teknologi jaringan dapat membuat, membina, memberikan, dan memfasilitasi pembelajaran, dan meningkatkan pengalaman siswa dan pengetahuan. (F. Li et al. 2014). Waktu sekarang mengharuskan orang belajar pengetahuan baru dan keterampilan lebih dan lebih efektif dan efisien.Mendesak peningkatan kebutuhan untuk cara-cara inovatif untuk menyediakan pendidikan dari waktu menuju perubahan dramatis dalam teknologi dan organisasi pengajaran (Cervená, 2011).(Conkova 2013).

Dunia pendidikan sudah sewajarnya dalam menuntun dan membimbng para peserta didik dalam mengenal lebih jauh terhadap tekonologi pembelajaran di dalam proses pembelajaran. Peserta didik yang berasal dari generasi millennial pasti sudah tidak asing lagi dengan komputer atau gadget dan dunia internet.Hal itu dikarenakan dalam lingkungan kesehariannya mereka tidak lepas dari internet.Dapat diibaratkan bahwa internet bagaikan teman yang menemani dalam kehidupan sehari-hari.

Koontz motivasi adalah sebagai reaksi yang dimulai dengan kebutuhan, yang menimbulkan keinginan atau usaha untuk mencapai tujuan, yang lebih lanjut menimbulkan ketegangan, yaitu keinginan terpenuhi, mengarah pada tindakan yang mengarah ke tujuan dan akhirnya memenuhi keinginan (Suyono and Mudjanarko 2017).

\section{METODE}

Jenis penelitian yang dilakukan terhadap pembahasan pada artikel ini adalah penelitian kuantitatif deskriptif dengan disain One-shot case study. Menurut Sugiyono, penelitian 
kuantitatif merupakan penelitian yang berlandaskan pengumpulan data menggunakan instrumen penelitian dengan tujuan untuk menguji hipotesis yang telah ditetapkan. Menurut penelitian deskriptif yaitu penelitian yang dilakukan untuk mengetahui nilai variabel mandiri, baik satu variabel atau lebih. Sehingga penelitian kuantitatif deskriptif merupakan data yang diperoleh dari sampel populasi penelitian dianalisis sesuai dengan metode statistik yang digunakan. Disain One-shot study adalah perlakuan tertentu pada suatu kelompok subjek kemudian dilakukan pengukuran terhadap variabel terikat. Pola desain One-shot study adalah sebagai berikut:

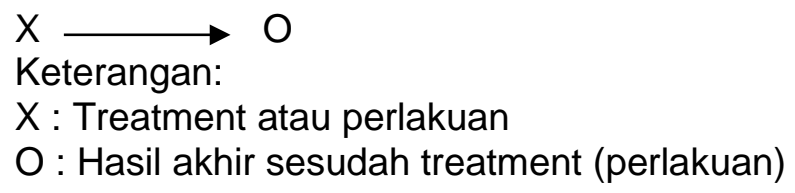

Subyek penelitian dilakukan pada siswa kelas XI IPS semester 1 tahun pelajaran 2020/2021 SMA Islamic Village dengan sampel pada penelitian berjumlah 26 siswa. Instrumen yang digunakan adalah tes hasil belajar dan data pembelajaran Elearning diperoleh dengan menggunakan lembar observasi. Tes hasil belajar terlebih dahulu dilakukan uji validitas dan reliabilitas. Dalam pengumpulan data, langkah-langkah yang dilakukan antara lain mempersiapkan instrumen, menentukan subyek penelitian, dan melakukan pembelajaran sesuai dengan disain. Selama proses pembelajaran observer melakukan observasi untuk mengukur motivasi belajar siswa.

a. Uji Validitas

$$
\mathbf{r}_{\mathrm{xy}}=\frac{N\left(\sum X Y\right)-\left(\sum X\right)-\left(\sum Y\right)}{\left[N \sum X^{2}-\left(\sum X^{2}\right)\right]\left[N \sum Y^{2}-\left(\sum Y\right)^{2}\right]}
$$

$$
\begin{aligned}
& \text { Keterangan: } \\
& \mathrm{xyr}=\text { koefisien korelasi antara } \mathrm{x} \text { dan } \mathrm{y} \\
& \mathrm{N} \text { = jumlah siswa } \\
& \mathrm{x}=\text { skor instrumen } \\
& \mathrm{y}=\text { skor total }
\end{aligned}
$$

Setelah dihitung $r$ dibandingkan dengan $r$ tabel ( $r$-product moment) dengan taraf signifikansi $5 \%$, jika $r$ hitung $>r$ tabel maka dikatakan soal valid.

b. Uji Reliabilitas

Soal yang diuji reliabilitasnya dalam hal ini hanya soal-soal yang valid. Uji reliabilitas dalam hal ini yaitu dengan menggunakan rumus Alpha Cronbach, penghitungan ini peneliti lakukan secara manual. Berdasarkan penghitungan dapat diketahui bahwa nilai reliabilitas instrumen yaitu 0,916. Berdasarkan tabel kriteria reliabilitas maka termasuk pada kategori tinggi, sehingga instrumen pernyataan pada angket motivasi belajar siswa pada Mata Pelajaran Sejarah bersifat sangat reliabel dan dapat digunakan untuk pengukuran.

Data dalam penelitian yang diperoleh berupa hasil belajar dan data pembelajaran Elearning dalam proses pembelajaran. Pengujian hipotesis yang digunakan untuk 
mengetahui pengaruh model pembelajaran Elearning terhadap motivasi belajar siswa yang digunakan analisis korelasi dan uji regresi linear dengan program SPSS 16.

\section{HASIL DAN PEMBAHASAN}

a. Analisis instrumen Instrumen yang digunakan dalam penelitian ini telah memenuhi persyaratan dalam uji validitas dan uji reliabilitas. Uji hubungan dan pengaruh dalam penelitian ini akan dilakukan uji regresi dengan menggunakan SPSS 16.

b. Deskripsi hasil penelitian

Data yang digunakan pada penelitian ini adalah data hasil data model pembelajaran Elearning terhadap motivasi belajar siswa hasil sebagai berikut.

1) Adapun motivasi belajar siswa yang diperoleh nilai rata-rata (mean) $=82,9091$ dan standar deviasi (standar deviation) $=5,95742$.

2) Pembelajaran Elearning Adapun nilai rata-rata (mean) dari pembelajaran Elearning $=86,4545$ dan standar deviasi pembelajaan Elearning $=6,34608$. 3) Uji hipotesis

Analisis data dengan menghitung koefisien korelasi dan uji signifikannya kemudian dilanjutkan dengan menentukan persamaan regresinya, dalam perhitungan penelitian ini menggunakan SPSS 16 agar dapat mengetahui pengaruh model pembelajaran Elearning terhadap motivasi belajar siswa.

Tabel 1. Uji Pengaruh Model Pembelajaran E-learning terhadap motivasi belajar belajar siswa.

\begin{tabular}{lll}
\hline & $\begin{array}{l}\text { Model Pembelajaran E- } \\
\text { Learning }\end{array}$ & Motivasi Belajar \\
\hline Model Pembelajaran E- & 1 & 475 \\
Learning & & 140 \\
$\mathrm{~N}$ & 26 & 26 \\
Motivasi Belajar & 475 & 1 \\
$\mathrm{~N}$ & 140 & \\
\hline
\end{tabular}

Signifikan hasil

korelasi

Hipotesis:

$\mathrm{HO}$ : Tidak ada pengaruh model pembelajaran Elearning terhadap motivasi belajar

$\mathrm{Ha}$ : ada pengaruh model pembelajaran Elearning terhadap motivasi belajar Dasar pengambilan keputusan: Jika probabilitasnya $>0,05$ maka $\mathrm{H} 0$ diterima Jika probabilitasnya $<0,05$ maka $\mathrm{H} 0$ diterima Diperoleh $\alpha=0,140>0,05$ sehingga $\mathrm{HO}$ ditolak. Jadi, ada pengaruh antara model pembelajaran Elearning 
terhadap Motivasi belajar siswa. Kesimpulan: Koefisien korelasi yang ditemukan signifikan, yaitu dapat digeneralisasikan ke seluruh sampel yang diambil.

Hipotesis kedua

Tabel 2. Uji Pengaruh Elearning terhadap Motivasi Belajar Siswa

\begin{tabular}{lllll}
\hline Model & Unstandardiced & Standardiced $t \quad$ sig \\
\cline { 2 - 4 } & Coefficient & & \\
B & & & \\
error & & &
\end{tabular}

$\begin{array}{llllll}\text { 1. constant } & 44.533 & 25.972 & & 1.715 & .121 \\ & .506 & .313 & .475 & 1.618 & .140\end{array}$

Pada tabel diatas dapat menunjukkan persamaan regresi dari variabel Pengaruh Model Pembelajaran Elearning terhadap Motivasi Belajar Siswa. Diperoleh persamaan regresi $Y=44,533+0,506 x$, artinya setiap penambahan variabel pengaruh model pembelajaran Elearning, maka variabel motivasi belajar siswa bertambah sebesar 0,506 satuan.

\section{SIMPULAN}

Dasar pengambilan keputusan: Jika probabilitasnya $>0,05$ maka $\mathrm{HO}$ diterima Jika probabilitasnya $<0,05$ maka $\mathrm{H} 0$ ditolak Diperoleh $\alpha=0,140>0,05$ sehingga $\mathrm{H} 0$ diterima. Jadi, ada pengaruh antara model pembelajaran Elearning terhadap Motivasi belajar siswa. Kesimpulan: Koefisien korelasi yang ditemukan signifikan, yaitu dapat digeneralisasikan ke seluruh sampel yang diambil. Hasil penelitian menunjukkan bahwa terdapat pengaruh antara model pembelajaran Elearning terhadap Motivasi belajar siswa.

\section{DAFTAR PUSTAKA}

Ahmadi, Abu. 2003. Ilmu Pendidikan. Jakarta : PT Rineka Cipta

DimyatidanMudjiono.2006. BelajardanPembelajaran.Jakarta:RinekaCipta.

E. Slavin, Robert. 2005. Cooperative Learning (Teori, Riset dan Praktik). Bandung: Nusa Media

Hamalik, Oemar. 2004. Proses Belajar Mengajar. Jakarta : PT Bumi Aksara

2008. Proses Belajar Mengajar. Jakarta : PT Bumi Aksara

Hasbullah. 2008. Dasar-dasar Ilmu Pendidikan. Jakarta : PT Raja Grafindo Persada Hugiono \& Poerwantana,P.K. 1987: Pengantar IImu Sejarah. Jakarta : PT Bina Aksara I Gde Widja. 1989. Pengantar Ilmu Sejarah: Sejarah dalam Perspektif Pendidikan. Semarang: Satya Wacana. 
Ibnu Hizam. 2007. "Kontribusi Minat Belajar dan Kemampuan Klarifikasi Nilai Sejarah dalam Pembentukan Sikap Nasionalisme" dalam Jurnal Penelitian

Keislaman, Vol. 3, No. 2, Juni 2007.

Latipun. 2002. Psikologi Eksprimen. Malang: UMM Press.

Muhibbin Syah, Psikologi Pendidikan dengan Pendekatan Baru, (Bandung: PT. Remaja Rosdakarya, 2000), cet. 5

Pidarta, Made. 2009. Landasan Kependidikan. Jakarta : Rineka Cipta

Purwoto, Agus. 2003. Panduan Laboratorium Statistik Inferensial. Jakarta: Gramedia Widiasarana Indonesia. Sudjana.2005. Metode Statistika. Bandung. PT. Tarsito.

Riduwan. 2004. Metode dan Teknik Menyusun Tesis. Bandung. Alfabeta.

2010. Model-Model Pembelajaran. Jakarta: PT Raja Grafindo.

Rusman. 2012. Model-model Pembelajaran: Mengembangkan Profesionalisme Guru. Jakarta: Rajawali Pers. Halaman 204

Sardiman A.M. 2004. Interaksi dan Motivasi Belajar-Mengajar. Jakarta : Rajawali Press 2008. Interaksi dan Motivasi Belajar-Mengajar. Jakarta : Rajawali Press

Sardiman A.M. 2012. Interaksi dan Motivasi Belajar-Mengajar. Jakarta : Rajawali Press 